\title{
Viral load and high prevalence of HR- HPV52 and 58 types in black women from rural communities
}

Lays Paula Bondi Volpini ${ }^{1 *}$ D, Jerusa Araújo Dias ${ }^{2}$, Luciana Bueno de Freitas ${ }^{3}$, Maria Carmen Lopes Ferreira Silva ${ }^{4}$, Angélica Espinosa Miranda ${ }^{1,5}$ and Liliana Cruz Spano ${ }^{1,4}$

\begin{abstract}
Background: The high-risk human papillomavirus (HR-HPV) infection is the main cause of cervical cancer development, and the most common types were included in the last approved nonavalent vaccine (9vHPV). Geographical, socioeconomic and ethnic barriers in developing countries challenge primary and secondary prevention measures of cervical cancer. We aimed to determine the prevalence of HPV infection and the viral load of HR-HPV 9vHPV-related types black women resident in rural semi-isolated communities.

Methods: A descriptive study was conducted with 273 cervical samples of women from rural communities of Southeastern Brazil. Viral DNA was amplified by PCR, the genotype was identified by Reverse Line Blot (RLB) and Restriction Fragment Length Polymorphism (RFLP), and real-time PCR was applied to determine the viral load.

Results: HPV frequency was 11.4\% (31/273), associated with the presence of cytological abnormalities (32.3\%; $p<$ 0.001). Thirty-one distinct genotypes were detected; HR-HPV occurred in $64.5 \%$ (20/31) of the samples and the most prevalent type were HPV52 > 58, 59. Multiple infections occurred with up to nine different genotypes. The viral load of HR-HPV 9vHPV-related types was higher in lesions than in normal cytology cases $(p=0.04)$; "high" and "very high" viral load occurred in HSIL and LSIL, respectively $(p=0.04)$.

Conclusions: We highlight that despite the low HPV frequency in the black rural women population, the frequency of HR-HPV was high, particularly by the HR-HPV52 and 58 types. Moreover, the HR-HPV viral load increased according to the progression from normal to lesion, being a potential biomarker to identify those women at higher risk of developing cervical lesions in this population.
\end{abstract}

Keywords: HPV, Viral load, Rural communities, Cervical cancer screening

\section{Background}

Human papillomavirus (HPV) is the most common sexually transmitted infection (STI), and the main cause of cervical cancer development [1]. According to the risk of oncogenic progression, HPV with tropism for the anogenital site are classified as low-risk (LR-HPV), high-

\footnotetext{
* Correspondence: layspaula90@gmail.com

'Infectious Diseases Post-Graduate Program, Federal University of Espírito Santo, Vitória, Brazil

Full list of author information is available at the end of the article
}

risk (HR-HPV), probable carcinogenic and undetermined-risk (UR-HPV) [2]. Among HR-HPV strains, the HR-HPV16 and 18 are responsible for the most cases of cervical cancer, followed by types 31,33 , 45,52 and 58 [3].

Cervical cancer is the third most common cancer among women worldwide, with an estimated 569,847 new cases, and 311,365 deaths in 2018 [4]. More than $84 \%$ of cases and deaths due to cervical cancer occur in women from low-resource regions of the World [5].

C C The Author(s). 2021 Open Access This article is licensed under a Creative Commons Attribution 4.0 International License, which permits use, sharing, adaptation, distribution and reproduction in any medium or format, as long as you give appropriate credit to the original author(s) and the source, provide a link to the Creative Commons licence, and indicate if changes were made. The images or other third party material in this article are included in the article's Creative Commons licence, unless indicated otherwise in a credit line to the material. If material is not included in the article's Creative Commons licence and your intended use is not permitted by statutory regulation or exceeds the permitted use, you will need to obtain permission directly from the copyright holder. To view a copy of this licence, visit http://creativecommons.org/licenses/by/4.0/. The Creative Commons Public Domain Dedication waiver (http://creativecommons.org/publicdomain/zero/1.0/) applies to the data made available in this article, unless otherwise stated in a credit line to the data. 
Control measures are based on the primary prevention with the bivalent HPV (16/18), tetravalent HPV (4vHPV$6 / 11 / 16 / 18$ ), and nonavalent (9vHPV- 6/11/16/18/31/33/ $45 / 52 / 58)$ vaccines, and on the secondary prevention by Pap test screening for precursor lesions, which reduced the cervical cancer in developed countries with organized screening programs [6]. Additional secondary tests based on the detection of HPV DNA have been introduced in the cervical cancer screening associated with cytology (co-test) or as primary screening in some developed countries [7]. Although Brazil has adopted Pap test as control measure for decades, besides $4 \mathrm{vHPV}$ since 2014, cervical cancer remains the third most common cancer in women, with approximately 16,370 new cases in 2018, corresponding to $41 \%$ of all cervical cancers cases in South America $[4,8]$.

Geographic, socioeconomic and ethnic barriers contribute to inequalities in the access to healthcare, as observed in black women, with a low socioeconomic status [9]. In this context are the Brazilian black women who live in rural African slave remnant communities, which health data are limited, especially regarding HPV prevalence and risk factors associated with cervical cancer $[10,11]$.

Additional strategies for cervical cancer prevention are imperative. Despite the low specificity, the HPV test has high sensitivity, allowing larger screening intervals and playing a promising role in cervical cancer prevention [12]. The association with potential biomarkers of high-grade cervical lesion (HSIL) and cancer, such as HPV viral load, could improves the specificity and will have potential benefit in reducing the incidence of cancer [13].

In this study, we aimed to determine the prevalence of HPV infection and the viral load of the HR-HPV genotypes correspondent to the types of the 9vHPV (9vHPVrelated) in black women resident in rural semi-isolated communities.

\section{Methods}

Patients, samples, sociodemographic data and ethic aspect

This is a descriptive study conducted between March 2016 to August 2017 in sexually active women from 16 semi-isolated communities located at Espírito Santo State, Southeastern Brazil. These communities are connected by unpaved roads of difficult access, between $6.21 \mathrm{mi}(10 \mathrm{~km})$ and $18.64 \mathrm{mi}(30 \mathrm{~km})$ from urban centers and from each other.

Women from 15 to 79 years, sexually actives, were included in this study. They answered a questionnaire about sociodemographic and behavioral data. Cervical samples were collected using a cytobrush, transported in Digene Specimen Transport Medium (STM, Qiagen
Incorporated, Valencia, CA), and maintained at $-70{ }^{\circ} \mathrm{C}$ for HPV investigation. Papanicolaou method was applied for the cytological evaluation at the Pathology Laboratory of the University Hospital of the Espírito Santo state by a single pathologist with expertise, and cervical abnormalities were interpreted according to the criteria defined in the Bethesda system [14].

This research obtained approval by the Ethical Research Council of the Center of Health Sciences of the Federal University of Espírito Santo, Brazil (Protocols n. 1.308.539 and 2.925.384). All participants signed an informed consent agreement. All the minors enrolled in this study and their parents/guardians signed the agreement consent (Resolution 466/12 of the National Health Council and its complementary) after the explanation of the study objectives.

\section{HPV detection and genotyping}

DNA was obtained using the QIAamp DNA Mini Kit (Qiagen, Valencia, CA, USA) according to the manufacturer's instructions, and the HPV DNA was detected by amplification with the PGMY09/11 set of primers [15]. PCR for the $\beta$-globin gene was performed in HPV negative samples as an extraction control and to assess the DNA integrity [16]. All the HPV positive samples were genotyped using a Reverse Line Blot (RLB) assay and Restriction Fragment Length Polymorphism (RFLP), as previously described $[17,18]$.

HPV genotypes identified in this study were classified as HR-HPV $(16,18,31,33,35,39,45,51,52,56,58,59)$, LR-HPV (6, 11, 40, 42, 43, 44, 54, 61, 70, 72, 81 and 89) and UR-HPV (2a, 3, 7, 10, 27, 28, 29, 30, 32, 34, 55, 57, $62,67,69,71,74,77,83,84,85,86,87,90$ and 91) [2]. Genotypes considered probable carcinogenic $(26,53,66$, 68, 73 and 82) were grouped with HR-HPV.

\section{Quantitative real-time PCR analysis for HPV DNA viral loads}

The viral load of HR-HPV 9vHPV-related types $(16,18$, $31,33,45,52$ and 58) was determined by quantitative real-time PCR (qPCR). Primers and probes for E6 and $E 7$ genes were used for HPV16 and HPV18, respectively, and $E 7$ for HPV31, 33, 45, 52 and $58[19,20]$.

The assay for HPV16 and 18 was performed according to Gravitt et al. (2003) [19] with modifications. In brief, $2 \mu \mathrm{l}$ of extracted DNA were added to $8 \mu \mathrm{L}$ of master mix containing 1X Buffer $(200 \mathrm{mM}$ Tris $\mathrm{HCl}$ and $500 \mathrm{mM}$ $\mathrm{KCl}), 20 \mathrm{mM}$ of each dATP, dGTP, dCTP and dTTP, $0.1 \mu \mathrm{M}$ of hydrolysis probe, $0.2 \mu \mathrm{M}$ of each primer, 0.6 $\mathrm{mM}$ of $\mathrm{MgCl}_{2}, 0.12 \mu \mathrm{M}$ of CXR Reference Dye (Promega Madison, WI, USA), and 1 Unit of Platinum Taq DNA Polymerase (Invitrogen Carlsbad, CA, USA). Thermal cycler conditions were previously described [19]. The assay for HPV 31, 33, 45, 52, and 58 was performed using $1 \mathrm{x}$ 
TaqMan ${ }^{\bullet}$ PCR Master Mix (Thermo Fisher Scientific, Waltham, MA, USA), as previously described [20].

The viral load was normalized using qPCR for the $\beta$ globin gene with primers described by Huang et al. (1989) [16]. The hydrolysis probe was designed to target the region between the primers using Primer3 v.0.4.0 [21]. The reaction condition proceeded as above described. All amplification assays were carried out on StepOnePlus equipment (Applied Biosystems, Foster City, CA, USA). Standard curves for absolute quantification of HPV types and $\beta$-globin were generated in 10 -fold serial dilutions $\left(10^{6}-10^{1}\right.$ copies of genome) with synthetic oligonucleotides fragments of $150 \mathrm{bp}$ (Thermo Fisher), designed from reference sequences of HPV genotypes and $\beta$-globin spanning the region between primers (GenBank ID: HPV16 - K02718, HPV18 - X05015, HPV31 J04353, HPV33 - M12732, HPV45 - X74479, HPV 52 X74481, HPV58 - D90400, $\beta$-globin - NC_000011.10). The viral load, expressed in copies per cell $(\mathrm{c} / \mathrm{c})$ was obtained dividing HPV copy number by half of the $\beta$-globin copy number, and was categorized as low $(1-10 \mathrm{c} / \mathrm{c})$, moderate $(11-100 \mathrm{c} / \mathrm{c})$, high $(101-1000 \mathrm{c} / \mathrm{c})$ or very high (>1000 c/c) [22]. HPV viral load was log-transformed $\left(\log _{10}\right)$ to graphic representation.

\section{Statistical analysis}

Statistical analyses were performed using SPSS 20.0 software for Windows (SPSS, Inc., Chicago, IL). Groups were compared using the Chi-square test or the Fisher exact test for qualitative characteristics, and using the Mann-Whitney and Kruskal Wallis tests for continuous ones. A $p$-value of less than 0.05 was considered statistically significant.

\section{Results}

A total of 273 black women participated in this study and HPV DNA was detected in $11.4 \%(31 / 273)$ of them. The behavioral and demographic information about the women enrolled in the study are shown in Table 1 . The age of patients ranged from 15 to 79 years, with a mean age of $41.9 \pm 14.2$ years.

Cytological results were obtained from 263 and $7.6 \%(20 / 263)$ presented cytological abnormalities. Ten of HPV positive samples (32.3\%) presented cytological abnormalities $(\mathrm{OR}=10.57,95 \%$ CI 3.95 to 28.28, $p<0.001)$.

Thirty-one distinct HPV genotypes were identified, and HR-HPV occurred in $64.5 \%(20 / 31)$ of the samples (Table 2). HPV52 was the most prevalent HR type (16.1\%), followed by 58,59 (12.5\% each), 31, 35, 39 and 53 types (9.4\% each) (Fig. 1). Multiple infections occurred in $48.4 \%(15 / 31)$, with up to nine distinct genotypes. Considering only the HR-HPV infection, multiple types occurred in $38.7 \%$ (12/31) and, of these, 33.3\% (4/
Table 1 Behavioral and demographic characteristics of black women from rural communities of Espírito Santo, Brazil $(n=273)$

\begin{tabular}{|c|c|c|c|}
\hline Characteristics & $\begin{array}{l}\text { HPV negative (\%) } \\
n=242\end{array}$ & $\begin{array}{l}\text { HPV positive (\%) } \\
n=31\end{array}$ & $p$ \\
\hline \multicolumn{4}{|c|}{ Distance from urban center (miles) } \\
\hline$\leq 6.21$ & $45(88.2)$ & $6(11.8)$ & 0.92 \\
\hline$>6.21$ & $197(88.7)$ & $25(11.3)$ & \\
\hline \multicolumn{4}{|c|}{ Use of contraceptive (Condom) } \\
\hline Yes & $65(89)$ & $8(11)$ & 0.90 \\
\hline No & $177(88.5)$ & $23(11.5)$ & \\
\hline \multicolumn{4}{|c|}{ Number of sexual partner (last year) } \\
\hline 1 & $175(87.1)$ & $26(12.9)$ & 0.17 \\
\hline$\geq 2$ & $67(93.1)$ & $5(6.9)$ & \\
\hline \multicolumn{4}{|c|}{ Last Papanicolaou test } \\
\hline$\leq 12$ months & $50(96.2)$ & $2(3.8)$ & 0.09 \\
\hline$>12$ months & $192(86.9)$ & $29(13.1)$ & \\
\hline
\end{tabular}

12) were present in cases with cytological abnormalities. Eighty percent of multiple infections occurred in women which reported to have only one sexual partner.

The viral load of HR-HPV positive samples, corresponding to the 9vHPV-related types, according to cytological results can be observed in Table 3. High and very high viral load was observed in all cytological results presenting HPV16, 31 and 52. Irrespective of genotype, high $(102.0 \mathrm{c} / \mathrm{c})$ and very high viral load $(1527.54 \mathrm{c} / \mathrm{c})$ were detected in HSIL and LSIL results, respectively, while low viral load was detected in normal $(0.31 \mathrm{c} / \mathrm{c})$ and ASCUS $(0.64 \mathrm{c} / \mathrm{c})$ results $(p=0.04)$ (Fig. 2$)$.

\section{Discussion}

Especially for disadvantaged populations, as black women living in rural areas, little is known about cervical cancer, even less about HPV infection rates and types [10, 11]. In Brazil, there are 3386 communities of African descendants of enslaved blacks, distributed in 24 states [23], and little attention is given to the issue of sexually transmitted infection $[10,11]$. In this study, we first show a low frequency of HPV infection in such women population but with a diversity of types and multiple infections, and a higher frequency of the HR-HPV 52 and 58 types over the HPV 16 type. Second, we demonstrate that the viral load of HR-HPV 9vHPV-related types increase between normal and cytological lesion.

We found an overall HPV frequency of $11.4 \%$ similar to the low HPV prevalence in similar Brazilian populations, of 12.6 and $13 \%[10,11]$. In women living also in rural areas worldwide, regardless of ethnicity, low rate ranging 10-26\% was described [24-26]. Conversely, these rates contrasts with those found in urban centers worldwide, which varied from $27.7-52,7 \%$ [27-29], in 
Table 2 HPV genotypes observed in black women, according to cytological data, from rural communities of Espírito Santo, Brazil

\begin{tabular}{|c|c|c|}
\hline Cytology $^{a}$ & $\begin{array}{l}\text { No of } \\
\text { samples }\end{array}$ & HPV genotypes ${ }^{b}$ \\
\hline ASCUS & 3 & $\mathbf{5 2}(2) / \mathbf{3 3}, 42, \mathbf{5 2}, 53, \mathbf{5 8}$ \\
\hline LSIL & 4 & $6 / 61 / 31,35,44,54,70 / 6, \mathbf{1 6}, \mathbf{3 1}, 35,39,56,61,66,84$ \\
\hline HSIL & 3 & $\mathbf{1 6 / 5 2 / 1 1 , 2 6 , 3 5 , 5 8}$ \\
\hline Normal & 21 & $\begin{array}{l}6 / 53 / 54 / \mathbf{5 8}(2) / 61(2) / 62 / 72 / 83 / 6,42 /, \mathbf{3 3}, 51 / 51,59 / 53,82 / 72,81,106 / 6,59,82 / \mathbf{1 8}, \mathbf{5 2}, 59 / 6,30,39,44,67 / \mathbf{1 8}, \\
26, \mathbf{4 5}, 59,61 / \mathbf{3 1}, 42,44,70,83 / 39, \mathbf{4 5}, 66,70,72\end{array}$ \\
\hline
\end{tabular}

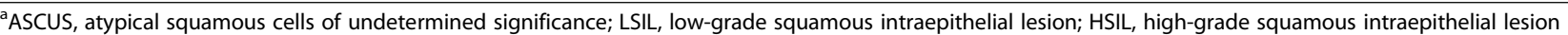

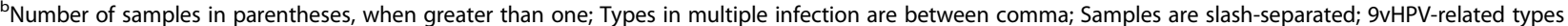
are highlighted

part suggesting that limited contact with urban centers could restrict the rate of HPV infection.

On the other hand, a high diversity of genotypes $(n=$ 31) and multiple HPV-types infection (48.4\%) occurred among the black rural women. Considering only the HR-HPV infection, multiple types (38.7\%) were higher than that described in those studies with similar black rural women $[10,11]$. Worldwide, multiple infection rates in women from urban centers, independent of lesion grade, have ranged from $16.7-41.8 \%$ [27-31]. There is no consensus whether the HPV types in multiple infections occur in a competitive or cooperative relationship. While Trottier et al. (2006) [32] suggest that an interaction between HPV types can increase the risk of lesion, other studies did not show an association with multiple HPV infection [33, 34].

In our study, HPV52 and 58 were the most frequent HR-HPV types, similar to those observed in black rural women of Northeastern Brazil [10, 11]. Sammarco and colleagues (2016) also found HPV58 as most frequent genotype, although in a population different from our study [35]. Interestingly, studies regarding HPV genotypes among different ethnic populations, have reported that HPV16 and 18 were less prevalent among Hispanic and non-Hispanic black women compared to non-Hispanic white women [36, 37]. These data are also supported by

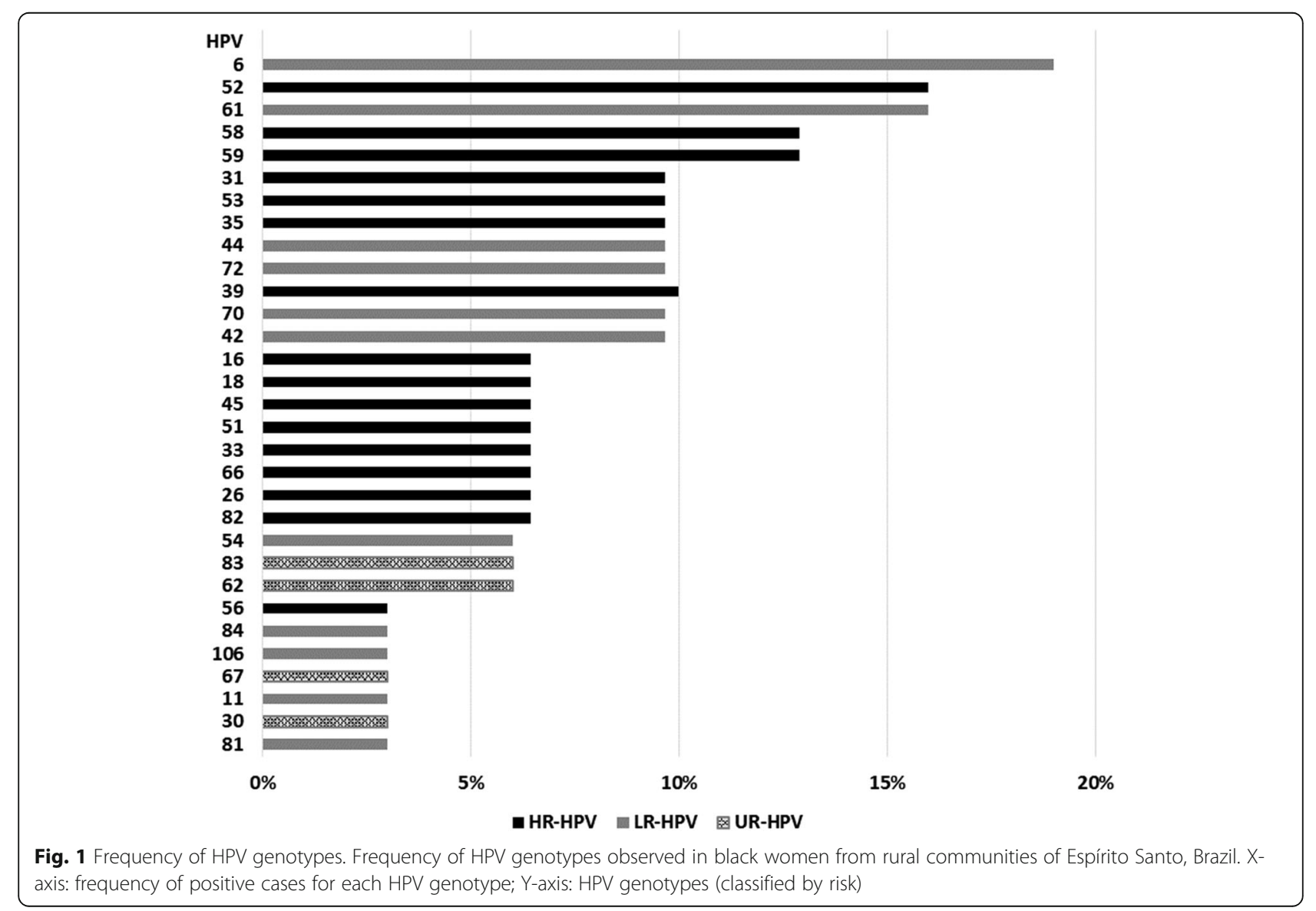


Table 3 Viral load classification according to HR-HPV types and correspondent cytological results of black women from rural communities of Espírito Santo, Brazil

\begin{tabular}{lll}
\hline Cytology $^{\mathbf{b}}$ & Viral load $^{\mathbf{a}}$ & HPV type \\
\hline ASCUS & Low & $33,52(2), 58$ \\
& Very high & 52 \\
LSIL & Moderate & 31 \\
\multirow{2}{*}{ HSIL } & Very high & 16,31 \\
& Low & 58 \\
Normal & High & 16,52 \\
& Low & $18(2), 33,45,58(2), 45$ \\
& Moderate & 31 \\
\hline
\end{tabular}

alow (1-10 c/c), moderate (11-100 c/c), high (101-1000 c/c) or very high $(>1000 \mathrm{c} / \mathrm{c})$

${ }^{\text {b} A S C U S}$, atypical squamous cells of undetermined significance; LSIL, low-grade squamous intraepithelial lesion; HSIL, high-grade squamous

intraepithelial lesion studies with African women from Kenya and Mozambique, which showed the HPV58 followed by HPV16, HPV53 and HPV18 types, and the HPV52 followed by HPV35, 16 and 53 as the most frequent in that population, respectively $[38,39]$. However, it is unclear why these women are less likely to be infected with HPV16 and 18. Vidal et al. (2014) [36] suggest that African descendant women, which harbor others HR-HPV than HR-HPV16 and 18, maybe more resistant or have lower exposure to infection by HR-HPV16 and 18. Other factors, as the composition of vaginal and cervical microbiota, may influence on the acquisition of certain types of HR-HPV, playing a role in the persistence of HPV and development and progression to cervical lesion [40, 41]. Besides, the ethnicity/race may influence the vaginal microbiota and Lactobacillus-dominated cervical microbiota is less common among African women [42-44].

Our results also draw attention to a greater benefit in the use of the 9vHPV vaccine to the detriment of the $2 \mathrm{vHPV}$ or $4 \mathrm{vHPV}$ in the prevention of cervical cancer in black women, at least from rural communities, because

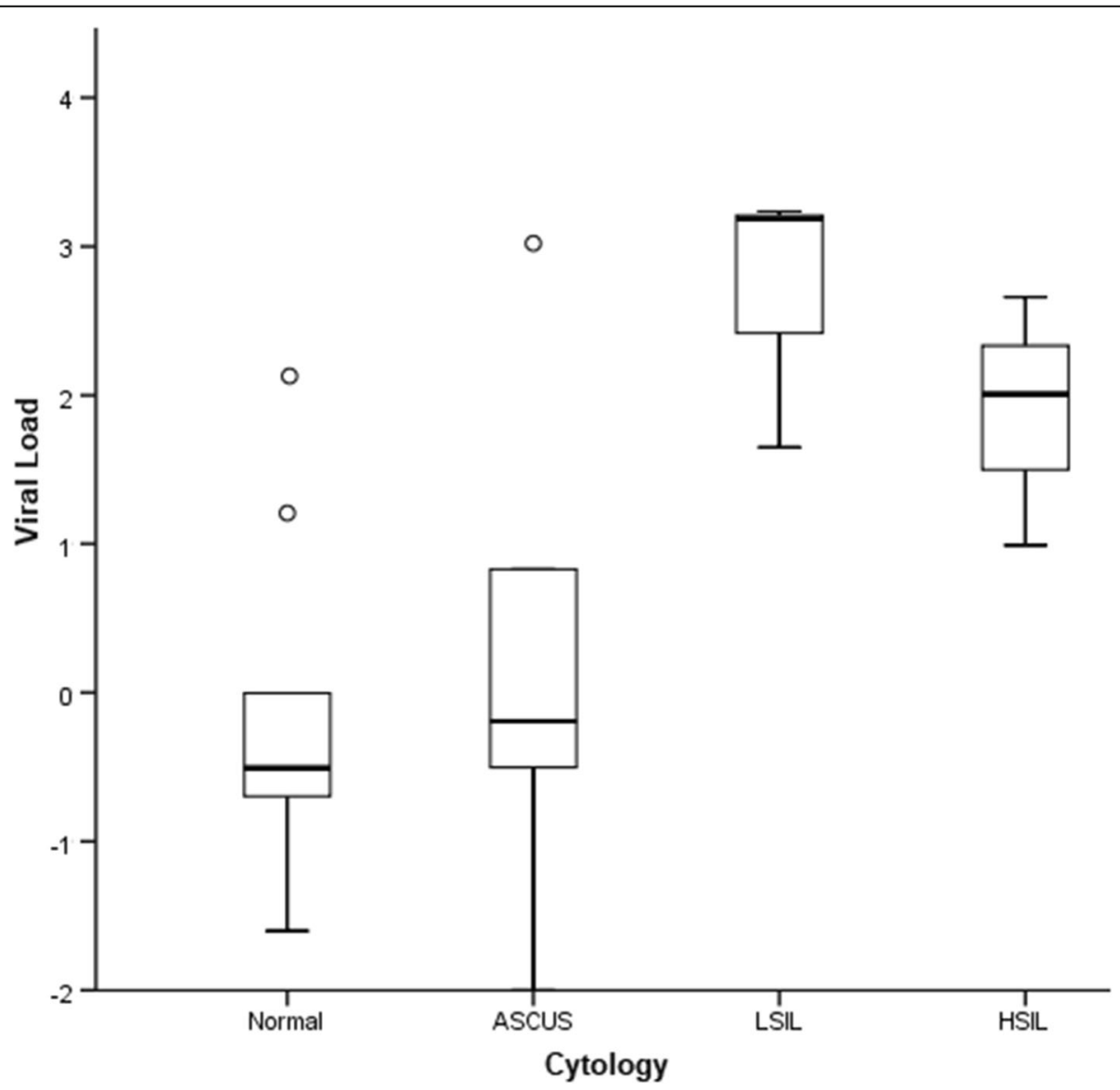

Fig. 2 Boxplot of the HPV viral load of black rural women, according to cytological results. Distribution of HPV cases among normal, ASCUS, LSIL and HSIL cytology $(p=0.04)$. Bands, boxes, and whiskers represent the median, interquartile range and minimum and maximum values of viral loads, respectively; circles represent outliers 
it contemplates the most frequent HR-HPV types that infect the black rural population (HPV52 and 58). Therefore, these findings may contribute with public health politics regarding the election of vaccines for specific populations.

We also showed that the viral load of HR-HPV 9vHPV-related types was higher in cases with cervical lesion than in normal cytology $(p=0.04)$. Most of the studies investigated HPV16 viral load, and some of them showed the association between an increase of the viral load and the cervical lesion $[45,46]$. The data on the viral load of HR-HPV other than HPV16 also showed similar results $[13,47,48]$. It is noteworthy that different HPV genotypes may have different mechanism to develop a high-grade cervical lesion and the viral load can modify the risk of precancerous disease [33]. This fact was demonstrated by Adcock and colleagues that, considering only the genotypes, the HPV16, 33 and 31 had greatest risk of pre-cancerous disease, and high viral loads for HPV18, 35, 52 and 58 carried more risk than intermediate levels for HPV16, 31 and 33 [33]. It is important to highlight that we observed a high and very high viral load of HPV 52 (the most frequent HPV genotype in this population) in normal and ASCUS results in women with a mean age of 42 years, living in semiisolated regions and with little access to health services. According to Brazilian guidelines for cervical cancer screening, repeat cytology is the management for such cytological results. However, considering our population studied and the low sensitivity of cytology, the HR-HPV test carried out simultaneously with viral load test could be useful to identify these women at higher risk of developing cervical lesions, increasing the interval of screening or referring them to immediate colposcopy instead repeat cytology.

This study had some limitations as the lack of cytological data for all participants, the absence of cervical histologic data, to confirm the precancerous lesions, as well as the small sample size due to difficulty of access to rural communities. However, we believe that the data provide valuable information about the profile of HPV infection in such population.

\section{Conclusions}

In conclusion, our data show a low frequency of HPV infection in black women from rural semiisolated communities, and the HR-HPV52 and 58 as the most types in contrast to HPV16. We also demonstrate an increase of HPV viral load of the 9vHPV-related types with cervical lesions cases. We believe that these findings may assist in the strategies for cervical cancer prevention, especially for disadvantaged populations.

\section{Abbreviations}

9vHPV: Nonavalent HPV vaccine; ASCUS: Atypical squamous cells of undetermined significance; c/c: Copies per cell; HSIL: High-grade squamous intraepithelial lesion; HPV: Human papillomavirus; HR-HPV: High-risk HPV; LRHPV: Low-risk HP; qPCR: Quantitative real-time PCR; RFLP: Restriction Fragment Length Polymorphism; RLB: Reverse Line Blot; STI: Sexually transmitted infection; UR-HPV: Undetermined-risk HPV

\section{Acknowledgements}

Not applicable.

\section{Authors' contributions}

LCS and AEM conceptualized the study and critically revised the manuscript. JAD performed the data and sample collection. MCLFS was responsible for cytology reporting. LPBV and LBF conducted DNA extraction, PCR, HPV genotyping and GPCR. LPBV conducted the data analysis, interpretation and manuscript writing. All authors read and approved the final manuscript.

\section{Funding}

This work was supported by Foundation for Research and Innovation Support of Espirito Santo State (FAPES, Grant numbers 86/2017 and 203/ 2018). The first author had a scholarship from FAPES. The funders had no role in the study design and collection, analysis and interpretation of data, and writing the manuscript.

\section{Availability of data and materials}

The data sets used and analyzed during the current study are available from the corresponding author on reasonable request.

\section{Declarations}

\section{Ethics approval and consent to participate}

This research obtained approval by the Ethical Research Council of the Center of Health Sciences of the Federal University of Espírito Santo, Brazil (Protocols n. 1.308.539 and 2.925.384). All participants signed an informed consent agreement. All the minors enrolled in this study and their parents/ guardians signed the agreement consent (Resolution 466/12 of the National Health Council and its complementary) after the explanation of the study objectives.

\section{Consent for publication}

Not applicable.

\section{Competing interests}

The authors declare that they have no competing interests.

\section{Author details}

${ }^{1}$ Infectious Diseases Post-Graduate Program, Federal University of Espírito Santo, Vitória, Brazil. Department of Nursing, University Center of Northern Espírito Santo, Federal University of Espírito Santo, São Mateus, Brazil. ${ }^{3}$ Multivix Faculty, Vitória, Brazil. ${ }^{4}$ Department of Pathology, Center of Health Sciences, Federal University of Espírito Santo, Vitória, Brazil. ${ }^{5}$ Department of Social Medicine, Center of Health Sciences, Federal University of Espírito Santo, Vitória, Brazil.

Received: 1 October 2020 Accepted: 5 April 2021

Published online: 17 April 2021

\section{References}

1. Centers for Disease Control and Prevention. Genital HPV infection-CDC fact sheet, vol. 1. Atlanta, GA: CDC; 2012. CDC Fact Sheets 2014;1-2 [cited 2019 Dec 16]. Available from: https://www.cdc.gov/std/hpv/HPV-FS-July-201 7.pdf

2. Muñoz N, Castellsague X, de Gonzalez AB, Gissmann L. Chapter 1: HPV in the etiology of human cancer. Vaccine. 2006;24:1-10.

3. Smith JS, Lindsay L, Hoots B, Keys J, Franceschi S, Winer R, et al. Human papillomavirus type distribution in invasive cervical cancer and high-grade cervical lesions: a meta-analysis update. Int J Cancer. 2007;121(3):621-32. https://doi.org/10.1002/ijc.22527.

4. Bruni L, Albero G, Serrano B, Mena M, Gómez D, Muñoz J, et al. ICO/IARC Information Centre on HPV and Cancer (HPV Information Centre). Human 
Papillomavirus and Related Diseases in the World. Summary Report 17 June 2019 [cited 2020 Mar 9]. Available from: https:/www.hpvcentre.net/sta tistics/reports/XWX.pdf.

5. Arbyn M, Weiderpass E, Bruni L, de Sanjosé S, Saraiya M, Ferlay J, et al. Estimates of incidence and mortality of cervical cancer in 2018: a worldwide analysis. Lancet Glob Health. 2020;8(2):e191-203. https://doi.org/10.1016/ S2214-109X(19)30482-6.

6. Arbyn M, Raifu AO, Weiderpass E, Bray F, Anttila A. Trends of cervical cancer mortality in the member states of the European Union. Eur J Cancer. 2009; 45(15):2640-8. https://doi.org/10.1016/j.ejca.2009.07.018.

7. Wentzensen N, Arbyn M, Berkhof J, Bower M, Canfell K, Einstein M, et al. Eurogin 2016 roadmap: how HPV knowledge is changing screening practice. Int J Cancer. 2017;140(10):2192-200. https://doi.org/10.1002/ijc.3 0579 .

8. Brasil, Ministério da Saúde/INCA [Internet]. Câncer do colo do útero, estatísticas. 2019 [cited 2019 Dec 17]. Available from: https://www.inca.gov. br/tipos-de-cancer/cancer-do-colo-do-utero.

9. Musselwhite LW, Oliveira CM, Kwaramba T, Pantano NDP, Smith JS, Reis RM, et al. Racial/ethnic disparities in cervical Cancer screening and outcomes. Acta Cytol. 2016;60(6):518-26. https://doi.org/10.1159/000452240.

10. Batista JE, Saddi VA, Carvalho KPA, Ribeiro AA, Segati KD, Carneiro MADS, et al. Human papillomavirus genotypes 68 and 58 are the most prevalent genotypes in women from Quilombo communities in the state of Maranhão. Brazil Int J Infect Dis. 2017;55:51-5. https://doi.org/10.1016/j.jijid.2 017.01.001.

11. Nascimento SD, Brandão VFCB, da Silva MAC N, Batista JE, MCL LB, et al. prevalence of human papillomavirus infection among women from Quilombo communities in northeastern Brazil. BMC Womens Health. 2018; 18(1):1-10. https://doi.org/10.1186/s12905-017-0499-3.

12. Schiffman M, Wentzensen N, Wacholder S, Kinney W, Gage JC, Castle PE. Human papillomavirus testing in the prevention of cervical cancer. J Natl Cancer Inst. 2011;103(5):368-83. https://doi.org/10.1093/jnci/dja562.

13. Marongiu L, Godi A, Parry JV, Beddows S. Human papillomavirus 16, 18, 31 and 45 viral load, integration and methylation status stratified by cervical disease stage. BMC Cancer. 2014;14(1):384. https://doi.org/10.1186/1471-24 07-14-384.

14. Solomon D, Davey D, Kurman R, Moriarty A, O'Connor D, Prey M, et al. The 2001 Bethesda system: terminology for reporting results of cervical cytology. JAMA. 2002;287(16):2114-9. https://doi.org/10.1001/jama.287.1 6.2114.

15. Gravitt PE, Peyton CL, Alessi TQ, Wheeler CM, Hildesheim A, Schiffman MH, et al. Improved amplification of genital human papillomaviruses improved amplification of genital human papillomaviruses. J Clin Microbiol. 2000;38(1): 357-61.

16. Huang SZ, Sheng M, Zhao JQ, Qiu XK, Zeng YT, Wang QS, et al. Detection of sickle cell gene by analysis of amplified DNA sequences. Yi Chuan Xue Bao. 1989:16(6):475-82.

17. Bernard HU, Chan SY, Manos MM, Ong CK, Villa LL, Delius H, et al. Identification and assessment of known and novel human papillomaviruses by polymerase chain reaction amplification, restriction fragment length polymorphisms, nucleotide sequence, and phylogenetic algorithms. J Infect Dis. 1994 Nov; 170(5):1077-85. https://doi.org/10.1093/infdis/170.5.1077.

18. Estrade C, Menoud PA, Nardelli-Haefliger D, Sahli R. Validation of a low-cost human papillomavirus genotyping assay based on PGMY PCR and reverse blotting hybridization with reusable membranes. J Clin Microbiol. 2011 Oct; 49(10):3474-81. https://doi.org/10.1128/JCM.05039-11.

19. Gravitt PE, Peyton C, Wheeler C, Apple R, Higuchi R, Shah KV. Reproducibility of HPV 16 and HPV 18 viral load quantitation using TaqMan real-time PCR assays. J Virol Methods. 2003 Sep;112(1-2):23-33. https://doi.org/10.1016/ S0166-0934(03)00186-1.

20. Winer RL, Xi LF, Shen Z, Stern JE, Newman L, Feng Q, et al. Viral load and short-term natural history of type-specific oncogenic human papillomavirus infections in a high-risk cohort of midadult women. Int J Cancer. 2014; 134(8):1889-98. https://doi.org/10.1002/ijc.28509.

21. Köressaar T, Lepamets M, Kaplinski L, Raime K, Andreson R, Remm M. Primer3_masker: integrating masking of template sequence with primer design software. Bioinformatics. 2018;34(11):1937-8. https://doi.org/10.1093/ bioinformatics/bty036.

22. Schlecht NF, Trevisan A, Duarte-Franco E, Rohan TE, Ferenczy A, Villa LL, et al. Viral load as a predictor of the risk of cervical intraepithelial neoplasia. Int J Cancer. 2003;103(4):519-24. https://doi.org/10.1002/ijc.10846.
23. Brasil. Fundação Cultural Palmares [Internet]. Certificação Quilombola [cited 2020 Mar 6]. Available from: http://www.palmares.gov.br/?page_id=37551.

24. de Lima SV, de Mesquita AM, Cavalcante FG, Silva ZP, Hora V, Diedrich T, et al. Sexually transmitted infections in a female population in rural northEast Brazil: prevalence, morbidity and risk factors. Tropical Med Int Health. 2003;8(7):595-603.

25. Sowjanya AP, Jain M, Poli UR, Padma S, Das M, Shah KV, et al. Prevalence and distribution of high-risk human papilloma virus (HPV) types in invasive squamous cell carcinoma of the cervix and in normal women in Andhra Pradesh. BMC Infect Dis. 2005;5(1):116. https://doi.org/10.1186/1471-23345-116.

26. Thapa N, Maharjan M, Shrestha G, Maharjan N, Petrini MA, Zuo N, et al. Prevalence and type-specific distribution of human papillomavirus infection among women in mid-western rural, Nepal- A population-based study. BMC Infect Dis. 2018:18(1):338. https://doi.org/10.1186/s12879-018-3175-9 Prevalence and type-specific distribution of human papillomavirus infection among women in mid-western rural, Nepal- A population-based study.

27. Pista A, Oliveira A, Verdasca N, Ribeiro F. Single and multiple human papillomavirus infections in cervical abnormalities in Portuguese women. Clin Microbiol Infect. 2011;17(6):941-6. https://doi.org/10.1111/j.1469-0691.2 010.03387.x.

28. Coser J, da Rocha BT, Simon D. Kazantzi Fonseca a S, Ikuta N, lunge VR. Prevalence and genotypic diversity of cervical human papillomavirus infection among women from an urban center in Brazil. Genet Mol Res. 2013;12(4):4276-85. https://doi.org/10.4238/2013.

29. Wheeler CM, Hunt WC, Cuzick J, Langsfeld E, Pearse A, Montoya GD, et al. A population-based study of human papillomavirus genotype prevalence in the United States: baseline measures prior to mass human papillomavirus vaccination. Int J Cancer. 2013;132(1):198-207. https://doi.org/10.1002/ijc.2 7608

30. Martín P, Kilany L, García D, López-García AM, Martín-Azaña MJ, Abraira V, et al. Human papillomavirus genotype distribution in Madrid and correlation with cytological data. BMC Infect Dis. 2011;11(1):316. https://doi. org/10.1186/1471-2334-11-316

31. Sammarco ML, Del Riccio I, Tamburro M, Grasso GM, Ripabelli G. Typespecific persistence and associated risk factors of human papillomavirus infections in women living in Central Italy. Eur J Obstet Gynecol Reprod biol. Eur J Obstet Gynecol Reprod Biol. 2013;168(2):222-6. https://doi.org/1 0.1016/j.ejogrb.2013.01.012.

32. Trottier H, Mahmud S, Costa M, Sobrinho JP, Duarte-Franco E, Rohan TE, et al. Human papillomavirus infections with multiple types and risk of cervical Neoplasia. Cancer Epidemiol Biomark Prev. 2006;15(7):1274-80. https://doi.org/10.1158/1055-9965.EPI-06-0129.

33. Adcock R, Cuzick J, Hunt WC, Mcdonald RM, Wheeler CM, Wheeler CM. Role of HPV genotype, multiple infections, and viral load on the risk of highgrade cervical Neoplasia. Cancer Epidemiol Biomark Prev. 2019;28(11):181624. https://doi.org/10.1158/1055-9965.EPI-19-0239.

34. Wentzensen N, Schiffman M, Dunn ST, Zuna RE, Gold MA, Allen RA, et al. Multiple HPV genotype infections in cervical cancer progression in the study to understand cervical Cancer early endpoints and determinants (SUCCEED). Int J Cancer. 2009;125(9):2151-8. https://doi.org/10.1002/ijc.24528.

35. Sammarco ML, Ucciferri C, Tamburro M, Falasca K, Ripabelli G, Vecchiet J. High prevalence of human papillomavirus type 58 in HIV infected men who have sex with men: a preliminary report in Central Italy. J Med Virol. 2016; 88(5):911-4. https://doi.org/10.1002/jmv.24406.

36. Vidal AC, Smith JS, Valea F, Bentley R, Gradison M, Yarnall KSH, et al. HPV genotypes and cervical intraepithelial neoplasia in a multiethnic cohort in the southeastern USA. Cancer Causes Control. 2014;25(8):1055-62. https:// doi.org/10.1007/s10552-014-0406-2.

37. Montealegre JR, Varier I, Bracamontes CG, Dillon LM, Guillaud M, Sikora AG, et al. Racial/ethnic variation in the prevalence of vaccine-related human papillomavirus genotypes. Ethn Health. 2019;24(7):804-15. https://doi.org/1 0.1080/13557858.2017.1373073

38. De Vuyst H, Parisi MR, Karani A, Mandaliya K, Muchiri L, Vaccarella S, et al. The prevalence of human papillomavirus infection in Mombasa. Kenya Cancer Causes Control. 2010;21(12):2309-13. https://doi.org/10.1007/s10552010-9645-z.

39. Edna Omar V, Orvalho A, Nália I, Kaliff M, Lillsunde-Larsson G, Ramqvist T, et al. Human papillomavirus prevalence and genotype distribution among young women and men in Maputo city. Mozambique BMJ Open. 2017;7(7): e015653. https://doi.org/10.1136/bmjopen-2016-015653. 
40. Mitra a, D a MI, Lee YS, Smith a, Marchesi JR, Lehne B, et al. Cervical intraepithelial neoplasia disease progression is associated with increased vaginal microbiome diversity. Sci Rep. 2015;5:16865. https://doi.org/10.1038/ srep16865.

41. Huang X, Li C, Li F, Zhao J, Wan X, Wang K, et al. Cervicovaginal microbiota composition correlates with the acquisition of high-risk human papillomavirus types. Int J Cancer. 2018;143(3):621-34. https://doi.org/10.1 002/ijc.31342.

42. Fettweis JM, Brooks JP, Serrano MG, Sheth NU, Girerd PH, Edwards DJ, et al. Differences in vaginal microbiome in African American women versus women of European ancestry. Microbiology. 2014;160(10):2272-82. https:/ doi.org/10.1099/mic.0.081034-0.

43. Ravel J, Gajer P, Abdo Z, Schneider GM, Koenig SSK, McCulle SL, et al. Vaginal microbiome of reproductive-age women. Proc Natl Acad Sci U S A. 2011;108(Suppl. 1):4680-7. https://doi.org/10.1073/pnas.1002611107.

44. Zhou X, Brown CJ, Abdo Z, Davis CC, Hansmann MA, Joyce P, et al. (2007) differences in the composition of vaginal microbial communities found in healthy Caucasian and black women. ISME J. 2007;1 (2):121-33. https://doi. org/10.1038/ismej.2007.12.

45. Hesselink AT, Berkhof J, Heideman DA, Bulkmans NW, Van Tellingen JE, Meijer CJ, et al. High-risk human papillomavirus DNA load in a populationbased cervical screening cohort in relation to the detection of high-grade cervical intraepithelial neoplasia and cervical cancer. Int J Cancer. 2009; 124(2):381-6. https://doi.org/10.1002/ijc.23940.

46. Xi LF, Hughes JP, Castle PE, Edelstein ZR, Wang C, Galloway DA, et al. Viral load in the natural history of human papillomavirus type 16 infection: a nested case-control study. J Infect Dis. 2011;203(10):1425-33. https://doi. org/10.1093/infdis/jir049.

47. Flores R, Papenfuss M, Klimecki WT, Giuliano AR. Cross-sectional analysis of oncogenic HPV viral load and cervical intraepithelial neoplasia. Int J Cancer. 2006;118(5):1187-93. https://doi.org/10.1002/ijc.21477.

48. Kim J, Kim BK, Jeon DS, Lee CH, Roh JW, Kim JY, et al. Type-specific viral load and physical state of HPV type 16, 18, and 58 as diagnostic biomarkers for high-grade squamous intraepithelial lesions or cervical Cancer. Cancer Res Treat. 2019;52(2):396-405. https://doi.org/10.4143/crt.2019.152.

\section{Publisher's Note}

Springer Nature remains neutral with regard to jurisdictional claims in published maps and institutional affiliations.

Ready to submit your research? Choose BMC and benefit from:

- fast, convenient online submission

- thorough peer review by experienced researchers in your field

- rapid publication on acceptance

- support for research data, including large and complex data types

- gold Open Access which fosters wider collaboration and increased citations

- maximum visibility for your research: over $100 \mathrm{M}$ website views per year

At $\mathrm{BMC}$, research is always in progress.

Learn more biomedcentral.com/submissions 